\title{
Cellulose pulp produced from bulrush fiber
}

\section{Vania Karine Dick Wille ${ }^{*}$ Cristiane Pedrazzi ${ }^{1}$ Jorge Luiz Colodette ${ }^{2}$ Rubens Chaves de Oliveira $^{3}$ Rodrigo Coldebella $^{1}$ Bruna Mohr Giesbrecht ${ }^{1}$ Angelo Fernando de Oliveira Saccol ${ }^{1}$}

${ }^{1}$ Departamento de Ciências Florestais, Universidade Federal de Santa Maria (UFSM), 97105-900, Santa Maria, RS, Brasil. E-mail: vaniakarine@hotmail.com. *Corresponding author.

${ }^{2}$ Laboratório de Celulose e Papel, Universidade Federal de Viçosa (UFV), Viçosa, MG, Brasil.

${ }^{3}$ Departamento de Engenharia Florestal (DEF), Universidade Federal de Viçosa (UFV), Viçosa, MG, Brasil.

\begin{abstract}
Brazil continues to use wood as the principal raw material source for the pulp industry; although, non-wood fibers have been revealed to be a competent substitute to produce paper with different and exceptional properties. Keeping this in focus, this study aimed to assess potential of Schoenoplectus californicus fibers (C. A. Mey.) Soják, commonly identified as bulrush or reed, in cellulosic pulp generation, as an alternative fiber source for the pulp and paper industry. On analyzing the chemical composition of reed fibers, extractives of lignin, carbohydrates, uronic acids and minerals were reported. Physico-chemical characteristics of reed-based cellulosic pulp were estimated including viscosity, hexenuronic acids, etc., as well as anatomical features of length, width, etc. From the chemical analyses of the reed the presence of high concentrations of extractives and silica was clear, making them unfit as raw material for cellulosic pulp production. Pulp kraft pulping process produced brown pulps low in viscosity (34.5m Pa.s) and hexenuronic acid content. Reed is thus classifiable as short-fiber source for pulp and paper industries.
\end{abstract}

Key words: Schoenoplectus californicus, caracterização química, processo kraft.

Produção de polpa celulósica a partir das fibras de junco

RESUMO: A madeira é a principal fonte de matéria prima utilizada nas indústrias de celulose no Brasil, porém o emprego de fibras não madeireiras pode ser uma alternativa satisfatória para a fabricação de papéis com propriedades diferenciadas e especiais. Nesse sentido, o objetivo desse trabalho foi avaliar o potencial das fibras de Schoenoplectus californicus (C.A. Mey.) Soják, popularmente conhecido como junco, na produção de polpa celulósica, como fonte alternativa de fibras para as indústrias do setor de celulose e papel. Nas fibras do junco foram realizadas análises de composição química, entre elas: teores de extrativos, lignina, carboidratos, ácidos urônicos e minerais. As polpas celulósicas produzidas a partir do junco foram avaliadas no que diz respeito às características físico-químicas (viscosidade, ácidos hexenurônicos, etc.) e anatômicas (comprimento, largura, etc.). As análises químicas demonstraram que as fibras do junco apresentam altos teores de extrativos e sílica, o que as tornam uma matéria prima desfavorável para a produção de polpa celulósica. O processo de polpação kraft do junco resultou em polpas marrons de baixa viscosidade (34,5m Pa.s) e com baixos teores de ácidos hexenurônicos. Ojunco pode ser classificado como fonte de fibras curtas para as indústrias de celulose e papel.

Palavras-chave: Schoenoplectus californicus, caracterização química, processo kraft.

\section{INTRODUCTION}

In Brazil, the cultivated species of eucalyptus and pine provide the major portion of the cellulosic pulp production. However, other potential sources include the non-wood fibers like bamboo (Bambusa vulgaris), sugarcane bagasse (Saccharum officinarum), flax (Linum usitatissimum), jute (Corchorus capsularis), Kenaf(Hibiscus cannabinus) and abaca (Musa textilis). These fibers are usually used to produce printing and writing papers, packaging and special papers (VAN DEN BERG, 2005).

Investigations on the utilization of grasses like bamboo in the generation of cellulosic pulps, has been done earlier by other authors
(BARRICHELO \& FOELKEL, 1975; AZZINI et al., 1987; BONFATTI J R., 2010;). However, there is a dearth of published works on the family Cyperaceae, of which Schoenoplectus californicus (C. A. Mey). Soják, commonly identified as reed, is a member, reported in southern Brazil. Data and information on Cyperaceae are available, although usually limited to references in floristic surveys, and confined to citations of the family species in local settings.

As Schoenoplectus californicus is a species with rapid growth cycles and less expensive than wood, the utilization of its fibers in industrial processes is interesting. In the state of Rio Grande do Sul, south Brazil, reeds occur in great quantities, showing satisfactory growth in the wetlands and humid 
locations, typical of this region. ROESSING (2007) stated that only very few studies are available on the cellular anatomy of the reed and that information on the development of this species is limited to the few cultivators, who grow it empirically and without any scientific basis.

Reeds commonly utilized as ornamental plants also find wide use in handicraft production due to their natural resistance and malleability. As reeds contain a high pulp percentage they are regarded as a potential raw material for paper production (CORDAZZO \& SEELIGER, 1988; SOUZA, 2003; SILVEIRA, 2007). As reeds are highly adaptable and grow fast in the Southern region of the state of Rio Grande do Sul, they are promising as a fiber source and is appealing for paper production as an attractive income source to riparian population who can easily cultivate, harvest, and benefit from the fibers.

Therefore, this study aimed to assess the potential of Schoenoplectus californicus fibers as an alternative raw material source for the cellulosic pulp production. Pulps produced were estimated in terms of physico-chemical and morphological characteristics of fibers.

\section{MATERIALS AND METHODS}

In July, during the cold and rainy period, the aerial portions of Schoenoplectus californicus of $1.54 \mathrm{~m}$ in length and $2.2 \mathrm{~cm}$ in diameter on average; respectively, were collected from the margins of a flooded land area on the Island of Marinheiros, in the district of the municipality of Rio Grande, in Rio Grande do Sul State.

Stems collected were cut just above the submerged portion, maintaining the cut limit of the part above the water layer, leaving the root portion for the plant to get reestablished and regrow the aerial parts. As these annual plants are developed in the Areas of Permanent Preservation (APP), samples were collected under prior Forest Authorization No. 01/2013 of the State Secretariat of the Environment - SEMA, through the Department of Forests and Protected Areas - DEFAP, agency Pelotas, taking care of the southern state.

Stems collected were hand-chopped and processed into chips ranging between 5 and $7 \mathrm{~cm}$ in length. A portion of the chips were milled to sawdust using a Willey mill, and stored after sorting them via sifting through 40/60 mesh sieves, in hermetically sealed glass jars for chemical analysis in future.

Due to the significance of chemical analysis and to collect more data on the fibrous raw material in question, chemical characterization of the reed fibers was done by employing the following analyses: the extractive content in acetone (TAPPI T 280 pm-99), total extractive content (TAPPI T $264 \mathrm{~cm}-97$-adapted), insoluble lignin (TAPPI $\mathrm{T}$ 222 om-98-adapted) and soluble TAPPI A 250) in acid, sugar composition (HPLC-PAD according to WALLIS et al., 1996), inorganic compounds (TAPPI T 211 and TAPPI T 244) and uronic acids (SUNDBERG et al., 1996).

The Schoenoplectus californicus fibers produced 45.7 Kappa kraft pulp. Using the electrically heated Regmed $^{\circledR}$ rotary digester provided with a thermometer and manometer, having 4 individual reactors of 2 liters capacity each, baking was done. Cooking time and temperature were monitored using a computational electronic controller at the control center of the other cooking settings. Parameters employed for kraft pulping included the following: Absolutely dry chips $=150 \mathrm{~g}$ (a.s.); Active alkali load (AA) $=7 \%$ (expressed as $\left.\mathrm{Na}_{2} \mathrm{O}\right)$; Sulfidity $=25 \%$; Liquor $/$ reed ratio $=5 / 1$; Maximum temperature $=170^{\circ} \mathrm{C}$; Time to achieve maximum temperature $=90$ minutes and time to achieve maximum temperature $=30$ minutes .

After being baked, fibers were expelled from the reactors and water-washed at room temperature, through a 150 mesh stainless steel screen. Fiber individualization was done in a 25 liter laboratory hydroculator, at an approximately $0.6 \%$ consistency. Cellulose pulp debugging was done in a Voith ${ }^{\circledR}$ laboratory scrubber provided with a perforated plate having $0.2 \mathrm{~mm}$ slits. After washing, defibration and purification, the cellulosic pulp was centrifugally dewatered at about $30 \%$ consistency, after which it was stored in a polyethylene bag for further analysis (TAPPI T 236cm-85), including viscosity (TAPPI T230 om-94) and hexenuronic acids (TENKANEN et al., 1999). In terms of the fiber dimensions of the pulps obtained, the length and width, thickness and width of the fiber lumen were assessed based on the Technical Standard of LCP 02 pp-97 and with the help of the Image-Pro Plus ${ }^{\circledR}$ Program.

\section{RESULTS AND DISCUSSION}

The results obtained for the reed fibers were compared mainly with work done with eucalyptus wood fibers and bamboo fibers. These comparisons are important because eucalyptus is the main short fiber used in the pulp and paper industries and bamboo, because it is like a reed, monocot (an alternative fiber) already used industrially. It is 
imperative to identify the chemical properties of the study material for technological research purposes (FONSECA, 2012). ANDRADE (2006) proposed that it was fundamental to evaluate the principal chemical components of wood, due to their great influence on the chemical pulping processes, thus altering the final product quality. For instance, ALMEIDA (2003) stated, that the extractive and lignin content of the wood had a direct influence on the alkali consumption, yield and delignification rate, enabling the determination of the potential of a raw material for cellulose pulp production.

In this study, reed fibers were characterized chemically, to quantify the extractive content in the acetone $(3.60 \%)$, total extractive content (11.94\%), insoluble lignin content $(22,19 \%)$ and solubility in acid $(2.70 \%)$, besides the total carbohydrate $(55.89 \%)$ and uronic acid (1.85\%) concentrations.

The total carbohydrate fraction termed holocellulose (cellulose plus hemicellulose), involves the cellulose fraction; whereas, other sugars (xylans, galactans, mannans and arabinans) represent the hemicellulose fraction (KLOCK et al., 2005). Other constituents of the reed samples included $34.30 \%$ glucans, $17.90 \%$ xylans, $0.90 \%$ galactans, $0.27 \%$ mannans and $2.58 \%$ arabinans. In Eucalyptus grandis and Eucalyptus urograndis wood PEDRAZZI (2009) identified the holocellulose levels of $62.10 \%$ and $61 \%$, respectively. GONCALEZ et al. (2002) identified holocellulose, lignin and the total extractives of 64.50, 27.30 and $8.20 \%$, respectively, in the Pinus taeda wood. PEREIRA et al. (2000); however, in their research on Eucalyptus benthamii wood identified the holocellulose, lignin and total extractive contents of $69.70,24.30$ and $6.00 \%$, respectively.

GUIMARÃES JR. et al. (2013); however, in their chemical characterization of the Bambusa vulgaris samples concluded that bamboo shows high holocellulose (67.58\%) and low lignin $(17.31 \%)$ contents when compared with the pine and eucalyptus woods.

On comparison of total carbohydrate content of the reed with the content assessed for wood and bamboo, in the researches mentioned above, it is clear that, although the reed fibers have a lower content, it can still find use as a raw material source in the cellulose industries. ALMEIDA (2003), proposed that the holocellulose content has a bearing on the yield of the pulping process, playing a crucial part in the economic aspect of the industry.

However, when the total extractive value in the reed (11.94\%) was compared with those of Pinus taeda (8.20\%) and Eucalyptus benthamii
$(6.00 \%)$, high extractive content of the reed exhibited some disadvantages in utilizing it as a raw material source for chemical pulping. BONFATTI JR., (2010) indicated that the undesirable chemical constituents of extractives and lignin affected the cellulose production process; by determining them, the estimates of the yield process and reagent consumption during pulping can be indirectly predicted.

With reference to the lignin concentration, GONCALEZ et al. (2002) and PEREIRA et al. (2000) reported that for reed the value assessed was $24.89 \%$, similar to that of the other raw materials utilized in the pulp and paper industries. Lignin cannot; therefore, be considered as a limiting chemical component in the use of reed fibers during the kraft process of cellulose production.

Reed also revealed a uronic acid value at a concentration of $1.85 \%$ on average, while eucalyptus wood registered between $4.70 \%$ and $5.00 \%$ (PEDRAZZI, 2009). According to ZANUNCIO \& COLODETTE (2011), the eucalyptus wood samples contained $4.05 \%$ to $5.29 \%$ uronic acid in the samples. Therefore, the value of uronic acid occurring in the reed samples was lower than that in eucalyptus wood. The authors emphasized the presence of uronic acids in some hemicelluloses, particularly the xylans. During the alkaline chemical pulping process, uronic acid structure was altered, and changed to hexenuronic acids, which reversed the pulp whiteness and raised the use of chemical reagents in the bleaching stage of the pulp industry.

Thus; although, the reed contains a higher xylan concentration than eucalyptus, the uronic acids occur in lower quantities. COLODETTE (2001) claimed that the chemical structure of the xylan monocotyledons is less acidic than the xylans in eucalyptus wood, causing this hemicellulose to be more resistant to chemical degradation during pulping.

Ash values of $76780 \mathrm{mg} \mathrm{kg}^{-1}$ were reported in the reed samples, showing on average a high silica content of $37,220 \mathrm{mg} \mathrm{kg}^{-1}$. As the total ash value for reed was reported to be $76,780 \mathrm{mg} \mathrm{kg}^{-1}$, it could be deduced that among the total inorganic compounds in the samples $48.48 \%$ was silica. Other inorganic compounds included magnesium (281 $\mathrm{mg} \mathrm{kg}^{-1}$ ), calcium (204.90 $\mathrm{mg} \mathrm{kg}^{-1}$ ), manganese (74.40 $\mathrm{mg} \mathrm{kg}^{-1}$ ), iron $\left(14.60 \mathrm{mg} \mathrm{kg}^{-1}\right)$ and copper $\mathrm{kg}^{-1}$.

Due to the high silica content in reed it is considered unfit as a raw material for cellulose production, because silica is an inorganic component that induces the wearing out of industrial equipment (FOELKEL, 2009). BOECHAT (2010), identified 
the occurrence of silica in non-wood materials acting as one of the principal reasons for problems in the cellulosic pulp industry.

Pulping process associated with cooking the reed fibers, produced pulp having 45.74 kappa number, $45.85 \%$ purified yield and $7.83 \%$ reject content. AZZINI et al. (1988) reported yields from the cellulose fibers between 45.67 and 56.78\% for Bambusa tuldoides. Prior, GUIMARÃES JR. et al. (2013), in their study on Bambusa vulgaris pulp recorded nearly $46 \%$ purified yield with kappa number between 45 and 55. On comparison bamboo pulps with those reed fibers identified in the current study, it is easily confirmed that yield values in cellulose for a kappa number of around 45 are similar between these two monocotyledons; thus the economics of pulp manufacturing processes to produce paper with the reed as raw material will be unaffected. BONFATTI Jr. (2010) stated that the purified yield shows the quantity of cellulose pulp post the purification process, that is, without the tailings, which is the basic parameter to qualify for pulping and the economics of the process.

With respect to the viscosity and concentration of the hexenuronic acids in the cellulosic reed pulps, the values of $34.50 \mathrm{mPa} . \mathrm{s}$ and $7.41 \mathrm{mmol} \mathrm{kg}^{-1}$, were reported, respectively. In their research, PEDRAZZI (2009) and QUEIROZ et al. (2004) used eucalyptus wood for kraft cooking and the resultant pulps showed viscosities between 63.20 and $69.50 \mathrm{mPa} . \mathrm{s}$ and a hexenuronic acid content of $60.70 \mathrm{mmol} / \mathrm{kg}$ on average. Reed pulp had a lower hexenuronic acid content compared with the cellulosic pulps of eucalyptus wood, an expected result as the reed fibers showed a low uronic acid content.

As the hexenuronic acids are not favorable to the cellulosic pulp bleaching process because they utilize reagents like chlorine, chlorine dioxide, ozone or peracids used in this process (ZANUNCIO \& COLODETTE, 2011), their presence makes the reed pulp unsuitable for bleaching.

The low viscosity (34.50mPa.s) reported for reed pulp is due to the higher rate of carbohydrate degradation during the pulping process, in which the alkali effectively degraded the holocellulose content of fibers, confirmed by the poorer yield observed in cooking. MOKFIENSKI (2004), showed that the cellulosic pulp viscosity was related to the integrity or intensity of the carbohydrate polymerization (cellulose and hemicellulose) resulting from the cooking.

LAMMI \& SVEDMAN (1999) reported that even at optimal levels of the kappa number (16-
18), the hardwood kraft pulps may exhibit certain variations in purified yield and quality, several of which could play a role in the variability of the quality of the fibrous raw material, although the others are definitely connected with the cooking process, which influence both chemical characteristics of lignin and carbohydrate fraction and concentration in the pulp, as confirmed in this study.

The morphology of the fibers and their chemical components facilitate predicting the behavior of pulp during the conditions under which the paper production process operates (CARPIM et al., 1987). In table 1 the results of the mean values for the wall thickness length, width, lumen diameter for reed pulps are listed.

From the values evident in table 1, the reed pulp fibers showed an average length of the $0.93 \mathrm{~mm}$ with an average width of $10.55 \mu \mathrm{m}$. The mean diameter $(3.95 \mu \mathrm{m})$ and the wall thickness $(3.30 \mu \mathrm{m})$ played no role in characterizing the fiber, but rather revealed the quality and resistance tests of the pulp products, not within the purview of this study.

According to GUO et al. (2010) the lengths ranged from 1.50 to $2 \mathrm{~mm}$, whereas the widths were between 17.90 and $19.10 \mu \mathrm{m}$ for the bamboo cellulose pulp fibers. TRUGILHO et al. (2005) in their evaluations of the unbleached cellulose pulp fibers of 15 Eucalyptus spp. clones reported mean fiber diameter of $0.92 \mathrm{~mm}$ and mean width of $15.76 \mu \mathrm{m}$. In his study, MOKFIENENSKI (2004) morphologically analyzed the bleached pulp fibers of some Eucalyptus spp., and reported that in Eucalyptus globulus the mean length was $0.77 \mathrm{~mm}$ and width was $21.00 \mu \mathrm{m}$, whereas for Eucalyptus grandis, the length hovered from 0.89 to $0.98 \mathrm{~mm}$ and the width from 20.80 to $22.10 \mu \mathrm{m}$, but for Eucalyptus urophylla, the length remained at $0.97 \mathrm{~mm}$ with the width at $20.81 \mu \mathrm{m}$.

When the results for reed showing the fiber dimensions of bamboo and eucalyptus pulps were compared, the reed pulp was seen to have fibers with similar lengths to those of eucalyptus pulp fibers but less for the bamboo pulps. As pulps are categorized based on fiber lengths, and eucalyptus is obviously a short fiber species, reed is classified as a fibrous source for short fiber cellulose production. BRACELPA (2010) stated that these fibers are suitable for the production of paper for printing and writing and sanitary uses, and despite their lower resistance, they enable the production of papers with a high degree of softness and absorption.

Conversely, when fiber width is considered, reed revealed poor results when compared with the fibers from the bamboo and eucalyptus pulps, it 
Table 1 - Fiber dimensions in chemical pulps of reed.

\begin{tabular}{lcccc}
\hline Average number of fibers measured & Length $(\mathrm{mm})$ & Width $(\mu \mathrm{m})$ & Lumen diameter $(\mu \mathrm{m})$ & Cell wall thickness $(\mu \mathrm{m})$ \\
\hline 1 a 25 & 0.91 & 10.34 & 3.71 & 3.85 \\
1 a 50 & 0.90 & 10.76 & 3.94 & 3.45 \\
1 a 75 & 0.90 & 10.57 & 3.95 & 3.32 \\
\hline 1 a 100 & 0.93 & 10.55 & 3.30 \\
\hline
\end{tabular}

was this characteristic that made the reed fibers unfavorable. CASTANHO \& OLIVEIRA (2000) identified that fibers having greater widths have higher chances of collapsing, which facilitates refining, offers a greater contact area between the fibers during paper sheet production and, hence, revealed greater resistance in the paper sheet produced.

\section{CONCLUSION}

Results gave sufficient evidence of the high levels of extractives and silica present in the reed fibers. Mat brown pulps could be produced having kappa number of 45.74 and purified yield of $45.85 \%$ containing $7.41 \mathrm{mmol} / \mathrm{kg}$ of hexenuronic acid and low viscosity of $34.50 \mathrm{mPa}$.s. Reed was used as source of raw material for the production of pulp cellulosic of short fiber.

\section{REFERENCES}

ALMEIDA, F.S. Influence of alkaline load on the Lo-Solids ${ }^{\circledR}$ pulping process for eucalyptus wood. 2003. 107f. Dissertation (Masters in Forest Resources) - University of São Paulo.

ANDRADE, A.S. Quality of wood, pulp and paper in Pinus taeda L.: Influence of productivity class age. 2006. 107f. Dissertation (Master in Forest Sciences) - Federal University of Paraná. BRAZILIAN CELLULOSE AND PAPER ASSOCIATION (BRACELPA). Cellulose - types and applications, 2010. Available from: <http://bracelpa.org.br/ bra2/?q=node/181>. Accessed: May 07, 2016.

AZZINI, A. et al. Joint production of cellulosic fibers and ethanol from bamboo. Bragantia, v.46, n.1, p.17-25, 1987.

AZZINI, A. et al. Basic density of stem and cellulosic fibers in progenies of Bambusa tuldoides Munro. In: ABCP ANNUAL CONGRESS, 1988, São Paulo. Anais... São Paulo: ABTCP 1988. p.17-23.

BARRICHELO, L.E.G.; FOELKEL, C.E.B. Production of sulphate pulp from wood mixtures of Eucalyptus saligna with small ratios of Bambusa vulgaris var. Vitatta. IPEF, n.10, p. 93-99, 1975.

BOECHAT, J.V.B. Production of tissue paper from sugarcane bagasse. 2010. 61f. Monograph (Specialist in Pulp and Paper Technology) - Federal University of Viçosa.
BONFATTI JR., E.A. Characterization of the anatomical, chemical and density properties of the species Bambusa vulgaris Schrad, ex. J.C. Wendl., for the production of Kraft cellulose with different alkali fillers. 2010. 67f. Final Course Work (Department of Forest Engineering) - University of Brasília.

CARPIM, M.A. et al. The influence of the number of fibers per gram on the optical properties of the paper. In: ANNUAL CONGRESS ABTCP, 20., 1987, São Paulo, SP. Anais... São Paulo: ABTCP, 1987. p.183-205.

CASTANHO, C.G; OLIVEIRA, R.C. Studies on the use of industrial fibrous waste from eucalypt kraft pulping in the production of recycled paper. In: ANNUAL CONGRESS OF CELLULOSE AND PAPER OF ABTCP, 33., 2000, São Paulo, SP. Anais... São Paulo: ABTCP, 2000. 17p.

COLODETTE, J.L. Chemistry of wood. Didactic material of the strictu sensu postgraduate course in pulp and paper technology. Module I. Viçosa: Federal University of Viçosa, Department of Forest Engineering, 2001. 196p.

CORDAZZO, C.V.; SEELIGER, U. Illustrated guide of coastal vegetation in the extreme south of Brazil. Rio Grande: FURG, 1988. $275 \mathrm{p}$.

FOELKEL, C. Individualization of Eucalyptus wood fibers for kraft pulp production. Eucalyptus Online Book \& Newsletter. July, 2009. 107 p. Available from: <ttp://www.eucalyptus.com.br/ disponiveis.html >. Acessed: May 6, 2016.

FONSECA, A. de S. Technological characterization of the fibers of Desmoncus polyacanthos Mart. 2012. $117 \mathrm{f}$. Dissertation (Master in Science and Technology of Madeira) Federal University of Lavras, Lavras, MG.

GONCALEZ, J.C. et al. Evaluation of Pinus taeda soda pulping with the addition of Antraquinone. In: AMERICAN CONGRESS OF CELLULOSE AND PAPER RESEARCHERS, 2002, São Paulo, SP. Anais... São Paulo? 2002. V.1, p.10-20.

GUIMARÃES JR., et al. Physical-chemical characterization of fiber and pulps of Bambusa vulgaris Schrad for use in polymer composites. Latin American Journal of Metallurgy and Materials, v.33, n.1, p.33-42, 2013. Available from: <http://www.scielo.org. ve/scielo.php?pid=S0255-69522013000100004\&script $=$ sci abstract\&tlng=en>. Accessed: May 8, 2016.

GUO, S. et al. Optimum bamboo kraft cooking - the influence of cooking conditions on cellulose and fiber properties. The paper, São Paulo v.71, n.7, p.63-76, 2010. Available from: <http://www. revistaopapel.org.br/publicacoes.php?id=1091>. Accessed: May 9, 2016. KLOCK, U. et al. Chemistry of wood. 3.ed. Curitiba: Federal University of Paraná, 2005. 86p. 
LAMMI, L.; SVEDMAN, M. Tailoring pulp quality in the pulping process. In: SEMINAR ON DELIGNIFICATION OF ABTCP, 2., 1999, São Paulo, SP. Anais... São Paulo: ABTCP, 1999.

MOKFIENSKI, A. Relative importance of basic density and chemical composition of wood of Eucalyptus spp. yield, bleachability and quality of kraft pulp. 2004. 153f. Thesis (PhD in Forest Sciences) - Federal University of Viçosa, Viçosa, MG.

PEDRAZZI, C. Influence of xylans on the production and properties of Eucalyptus pulps for papers. 2009. 211f. Thesis (Doctorate in Forest Sciences) - Federal University of Viçosa, Viçosa, MG.

PEREIRA, J.C.D. et al. Characteristics of the wood of some species of eucalyptus planted in Brazil. Colombo: Embrapa Forest, 2000. 113p. (Documents, 38).

QUEIROZ, S.C.S. Influence of basic wood density on kraft pulp quality of hybrid clones of Eucalyptus grandis W. HILL ex Maiden X Eucalyptus urophylla S.T. Blake. Revista Árvore, Viçosa-MG, v.28, n.6, p.901-909, 2004. Available from: $<\mathrm{http}: / / \mathrm{www}$. scielo.br/scielo.php?pid=S0100 67622004000600016\&script=sci_arttext $>$. Accessed: May 6, 2016. doi 10.1590/S0100-67622004000600016.

ROESSING, M. Production, morpho-anatomical and ornamental characterization and use of Juncus effusus L., in landscaping. 2007. 170f. Dissertation (Master in Agronomy) University of Passo Fundo, Passo Fundo, RS.

SILVEIRA, T.C.L. Impact of the cut of aquatic macrophytes Schoenoplectus californicus and Typha domingensis on macro invertebrate fauna: subsidies for sustainable extractivism. 2007. 129f. Dissertation (Master in Animal Biology) - Federal University of Rio Grande do Sul, Porto Alegre, RS.

SOUZA, G.C. de. Extractivism in a biosphere reserve area of the Atlantic Forest in Rio Grande do Sul: an ethnobiological study in Maquiné. 2003. 202f. Thesis (PhD in Botany) - Federal University of Rio Grande do Sul, Porto Alegre, RS.

SUNDBERG, A.K. et al. Determination of hemicelluloses and pectins in wood and pulp fibers by acid methanolysis and gas chromatography. Nordic Pulp and Paper Research Journal, v.11, p.216-220, 1996. Available from: <http://www.npprj.se/html/ np-viewarticleabstract.asp?m=7097\&mp=554>. Accessed: May 9, 2016. doi: 10.3183/NPPRJ-1996-11-04-p216-219

TAPPI (TECHINICAL ASSOCIATION OF PULP AND PAPER INDUSTRY). Tappi standard methods. Atlanta, 1983 1993, 1996 and 2000.

TENKANEM, M.J. et al. Determination of hexenuronic acid in softwood kraft pulp by three different methods. Journal Pulp and Paper Science, v.25, p.306-311, 1999. Available from: <https:// www.researchgate.net/publication/279555322_Determination of hexuronic acid in softwood kraft pulps by three different methods $>$. Accessed: May 5, 2016.

TRUGILHO, P.F. et al. Eucalyptus clones versus the production of cellulosic pulp. Forest Science, v.15, n.2, p.145-155, 2005. Available from: $<$ http://www.sifloresta.ufv.br/handle/123456789/11897>. Accessed: May 8, 2016. doi: 10.5902/198050981832.

VAN DEN BERG, E. Economic botany. 2005. 56f. Monograph (Specialization in Economic Botany) - Federal University of Lavras, Lavras, MG.

ZANUNCIO, A.J.V.; COLODETTE, J.L. Lignin and uronic acid contents in wood and eucalyptus cellulose pulp. Tree, v.35, n.2, p.341-347, 2011. Available from: <http://www.bibliotecaflorestal. ufv.br/handle/123456789/11202>. Accessed: May 8, 2016. doi: 10.1590/S0100-67622011000200018.

WALLIS, A.F.A. et al. Chemical analysis of polysaccharides in plantation eucalyptus woods and pulps. Appita Journal, v.4, p.258-262, 1996. Available from: <https://www.researchgate.net/ publication/285751329 Chemical analysis of polysaccharides in plantation_eucalypt_woods_and_pulps $>$. Accessed: May 5, 2016. 